\title{
The effects of calcium hydroxide-treated whole-plant and fractionated corn silage on intake, digestion, and lactation performance in dairy cows
}

\author{
D. E. Cook, ${ }^{*}$ R. W. Bender, ${ }^{*}$ K. J. Shinners, $†$ and D. K. Combs ${ }^{* 1}$ \\ ${ }^{*}$ Department of Dairy Science, and \\ †Department of Biological Systems Engineering, University of Wisconsin, Madison 53706
}

\begin{abstract}
The objective of this trial was to evaluate, in dairy cattle, the effects of calcium hydroxide treatment of whole-plant corn and a treatment applied to the bottom stalk fraction of the corn plant, achieved by harvesting corn in 2 crop streams. The treatments were calcium hydroxide-treated corn silage (TRTCS), toplage supplemented with calcium hydroxide-treated stalklage (TPL), a positive control of brown midrib corn silage (BMR), and a negative control of conventional whole-plant corn silage (WPCS). The toplage was harvested at a height of $82 \mathrm{~cm}$ with 2 of the 6 rows set as ear-snapping to incorporate higher tissues into the stalklage. Stalklage was harvested at $12 \mathrm{~cm}$, and other corn silages were harvested at $27 \mathrm{~cm}$. Sixteen pens, each with 8 Holstein cows averaging $70 \pm 25 \mathrm{~d}$ in milk and $46 \pm 11 \mathrm{~kg}$ of milk d ${ }^{-1}$, were assigned 4 per treatment in a completely randomized design. The diet was approximately $40 \%$ corn silage, $20 \%$ alfalfa silage, and $40 \%$ concentrate on a dry matter basis. A 2-wk covariate period with conventional corn silage was followed by an 8 -wk treatment period in which the 4 corn silage treatments were the only effective difference in diets. Cows fed TPL and TRTCS consumed more (1.9 and $1.4 \mathrm{~kg}$ of organic matter $\mathrm{d}^{-1}$, respectively) than did cows fed WPCS. Milk yield was greater for cows fed BMR, TPL, and TRTCS. Cows fed BMR and TPL produced 2.9 and $2.7 \mathrm{~kg} \mathrm{~d}^{-1}$, respectively, more energycorrected milk (ECM) than cows fed WPCS, and cows fed TRTCS had the greatest ECM production $(4.8 \mathrm{~kg}$ of ECM d ${ }^{-1}$ greater than cows fed WPCS). No differences in body weight or body condition scored were observed. Milk fat concentration was similar among treatments and milk protein concentration was reduced for TRTCS. Starch and neutral detergent fiber digestibility were greater for cows fed TRTCS.
\end{abstract}

Key words: alkali, calcium hydroxide, fractionated, corn silage, fiber digestibility

Received September 15, 2015.

Accepted December 8, 2015.

${ }^{1}$ Corresponding author: dkcombs@wisc.edu

\section{INTRODUCTION}

Increased digestibility of fiber and starch can improve dairy lactation performance (Oba and Allen, 1999, 2000a; Schwab et al., 2002; Ferraretto and Shaver, 2015). Increases in digestibility can be accomplished by crop selection, earlier maturity harvest, improved storage management, physical treatment and size reduction, or chemical treatment, among other approaches (Fahey et al., 1993). The use of calcium hydroxide has been proven to improve fiber digestibility of gramineous crop residue (Jackson, 1977; Haddad et al., 1994, 1998; Shreck, 2013). However, the aerobic stability of alkali-treated silage at moisture contents greater than $400 \mathrm{~g} \mathrm{~kg}^{-1}$ can negate benefits of treatment (Deschard et al., 1988).

Corn harvested in 2 fractions allows for new ration formulations and targeting of low-quality roughage to animals such that their performance is not negatively affected. Corn silage with higher levels of starch and with higher fiber digestibility could replace whole-plant corn silage and some of the corn in a lactating dairy diet. Whole-plant corn silage (WPCS) containing highly digestible NDF can reduce the limitations of rumen fill, thereby allowing for greater intake and production (Mertens, 1987; Oba and Allen, 1999). Treated stalks could be used in late lactation, the dry period, and in heifer diets.

Brown midrib (BMR) mutant lines of corn have improved fiber digestibility, primarily due to a reduction in the lignin concentration of the NDF (Jung et al., 2012). Brown midrib lines can also suffer from lower yields, susceptibility to lodging, poor early season vigor, and slower early season growth rates (Miller et al., 1983). Mechanical and chemical treatments of corn silage can improve fiber digestibility while avoiding the agronomic disadvantages of BMR; however, such treatments result in increased costs and logistical harvest challenges.

The purpose of this study was to evaluate the effects of alkali treatment of corn fiber on the performance of lactating dairy cows in relation to a positive and negative control. The alkali treatment primarily exerts its effect by increasing the proportion of potentially 
digestible fiber, similar to BMR corn (Haddad et al., 1994, 1998; Oba and Allen, 2000a). The lower portion of the corn stalk contains the highest concentration of indigestible fiber. We hypothesize that feeding corn silage where the lower portion of the plant is treated with calcium hydroxide will improve intake and production over that of untreated corn silage, similar to BMR corn. We further hypothesize that whole-plant corn treated with calcium hydroxide will improve milk production to a greater degree than partial plant treatment.

\section{MATERIALS AND METHODS}

\section{Crops and Harvest}

A conventional corn, Pioneer P9910AMX [99 d comparative relative maturity (CRM); Pioneer, Johnston, IA], and a BMR corn hybrid containing the bm3 gene mutation, Mycogen F2F499 (99 d CRM; Mycogen Seeds, Indianapolis, IN), were planted on May 30 and 31, 2014, respectively, at the University of WisconsinArlington Agricultural Research Station (Arlington, WI). Crops were grown under the same tillage, fertilizer application, and weed control practices. All corn crops were harvested between September 30, 2014 and October 1, 2014, using a self-propelled forage harvester (JD 6950, John Deere, Moline IL) set for a $1.95-\mathrm{cm}$ theoretical length of cut and equipped with conventional processing rolls set for a 2-mm clearance. Harvest was conducted at stubble heights of 26,26 , and $28 \mathrm{~cm}$ for conventional WPCS, BMR whole-plant corn silage, and calcium hydroxide-treated corn silage, respectively. Two new products were harvested using an ear-snapping head that uses a modified deck plate to harvest a mechanically adjustable proportion of the top of the plant and the ear in the first pass, yielding toplage (Nigon et al., 2016). For this study, 2 rows had only the ear harvested and 4 rows were harvested at a height of 82 $\pm 5 \mathrm{~cm}$. In a second pass, the remaining stalks were cut using a windrower (JD 4995, John Deere) at a height of $12 \pm 2 \mathrm{~cm}$. Following a day of field wilting, in a third pass, a self-propelled forage harvester (JD 6950, John Deere) with a windrow pickup head was used to harvest the stalk fraction of the corn plant, yielding stalklage. Of the total harvested fraction, stalklage comprised $17.8 \%$ of the harvested DM and toplage $82.2 \%$ of the harvested DM. The conventional corn used for WPCS, toplage, stalklage, and calcium hydroxide-treated corn silage was harvested in series from multiple locations in the field to reduce field location variation. The BMR corn was grown in an immediately adjacent field under similar soil, fertility, and topographic conditions.

Dry matter content of the crops at harvest was 440 , $395,395,336$, and $336 \mathrm{~g}$ of DM ( $\mathrm{kg}$ of fresh matter $)^{-1}$ for toplage, WPCS, calcium hydroxide-treated corn silage, BMR, and stalklage (Table 1), respectively. Whole-plant corn and the stalks destined for alkali treatment were harvested directly into a reel-type TMR mixer (Kuhn RC295, Kuhn North America, Brodhead, WI) and mixed with calcium hydroxide at a rate of $50 \mathrm{~g} \mathrm{Ca}(\mathrm{OH})_{2}(\mathrm{~kg} \text { of crop DM})^{-1}$ for approximately $10 \mathrm{~min}$ to ensure thorough mixing. The other crops were harvested into trucks and were not exposed to potential particle size reduction by mixing. The crops were subsequently packed into plastic silage bags and stored anaerobically for more than $60 \mathrm{~d}$.

\section{Cows and Diets}

One hundred twenty-eight lactating Holstein cows, averaging $70 \pm 25$ DIM and $46 \pm 11 \mathrm{~kg}$ of milk d ${ }^{-1}$ at trial initiation, were stratified by parity, DIM, and level of production and assigned to 16 pens of 8 cows each in the University of Wisconsin sand-bedded freestall barn (Emmons Blaine Dairy Research Center, Arlington, WI). Pens were randomly assigned to 1 of 4 treatments in a completely randomized design with a covariate adjustment. The study was performed over 11 wk, including a 2-wk covariate period, 1-wk transition to experimental diet, and $8 \mathrm{wk}$ of feeding the experimental diets. Experimental diets were designed to contain (DM basis) corn silage (41.6\%), alfalfa silage (19.4\%), high-moisture shelled corn $(14.8 \%)$, whole cottonseed $(3.3 \%)$, and concentrate mixture and ground limestone $(20.6 \%)$, where treatments varied by source of corn silage and were substituted on an equivalent $\mathrm{OM}$ amounts of the different corn silages. The 4 diets (Table 2) were a negative control (WPCS), a positive control (BMR), calcium hydroxide-treated corn silage (TRTCS), and toplage (TPL). The TPL diet contained $347 \mathrm{~g}$ (DM) of toplage and $76 \mathrm{~g}$ (DM) of calcium hydroxide-treated stalklage $(1 \mathrm{~kg} \text { of TMR DM })^{-1}$, a ratio similar to the harvested mass ratio. The TPL ration was formulated not for optimal performance but rather to compare the effects on fiber digestibility due to treatment of the lower portions of the corn stalk, although we recognize that a substantial benefit of a fractionated crop is the ability to further optimize the ration beyond what the whole plant yields in the field. Feeding commenced on Dec 4, 2014, and took place when average ambient temperatures were below freezing. The covariate period diet was similar to the treatment diets using the herd nonexperimental corn silage instead of treatment corn silages. Ground limestone was added to all diets to meet the nutrient requirements for calcium, except for TRTCS, which had an excess of calcium due to treatment (NRC, 2001). In Table 2, the TMR composition presented represents ingredients as they were actually 
Table 1. Harvest conditions, composition, and particle size of forages

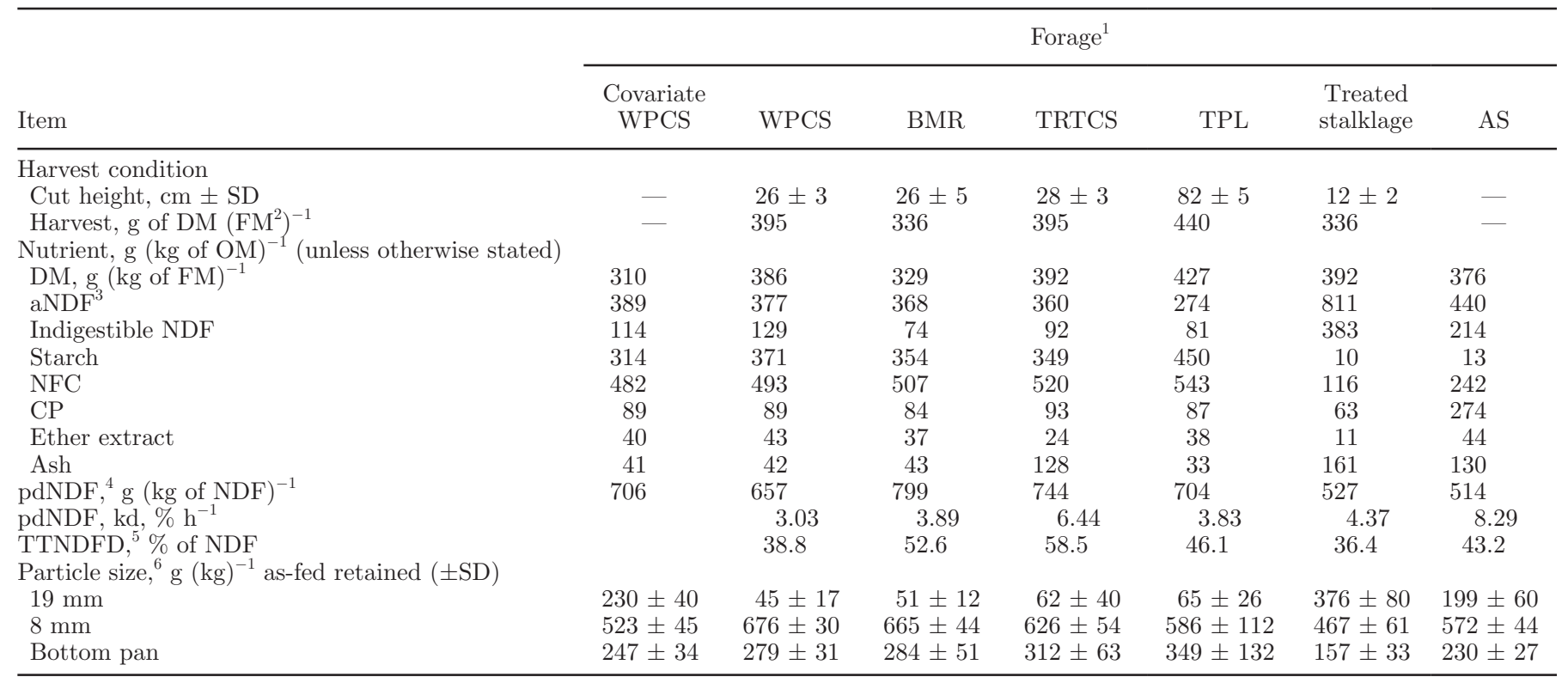

${ }^{1}$ WPCS $=$ whole-plant corn silage; BMR = brown midrib corn silage; TRTCS = treated whole-plant corn silage; TPL $=$ toplage and treated stalklage; $\mathrm{AS}=$ alfalfa silage.

${ }^{2}$ Dry matter content at harvest.

${ }^{3}$ aNDF $=$ amylase-treated NDF.

${ }^{4} \mathrm{pdNDF}=$ potentially digestible $\mathrm{NDF} ; \mathrm{kd}=$ rate of degradation of pdNDF.

${ }^{5}$ TNDFD $=$ total-tract NDF digestibility prediction (Lopes et al., 2015).

${ }^{6}$ Particle size was measured using the Penn State Particle Size Separator (Heinrichs et al., 1999).

mixed for the trial and thus deviate slightly from the planned diets. All cows were injected with bST (Posilac, Monsanto Company, St. Louis, MO) every $14 \mathrm{~d}$ beginning the first day of the covariate period.

Diets were fed daily at $0800 \mathrm{~h}$ as a TMR on an ad libitum basis. Daily pen intake was measured as the difference between the amount of as-fed TMR offered and the amount of as-is orts using Feed Supervisor software (Supervisor Systems, Dresser, WI), with that amount then multiplied by the DM content of the TMR to determine DMI. Milk production, feed offered, and orts were recorded daily throughout the experiment.

Table 2. Ingredient composition $\left[\mathrm{g}(\mathrm{kg} \text { of } \mathrm{TMR} \mathrm{DM})^{-1}\right]$ for experimental diets

\begin{tabular}{|c|c|c|c|c|c|}
\hline \multirow[b]{2}{*}{ Item } & \multirow[b]{2}{*}{ Covariate } & \multicolumn{4}{|c|}{ Component $^{1}$} \\
\hline & & WPCS & BMR & TPL & TRTCS \\
\hline Corn silage, covariate & 411 & & & & \\
\hline WPCS & & 417 & & & \\
\hline BMR & & & 413 & & \\
\hline Toplage & & & & 347 & \\
\hline Treated stalklage & & & & 76 & \\
\hline Treated corn silage & & & & & 439 \\
\hline Ground limestone & 14.0 & 13.9 & 14.0 & 6.8 & \\
\hline Alfalfa silage & 199 & 193 & 195 & 192 & 187 \\
\hline Ground high-moisture shell corn & 150 & 149 & 150 & 147 & 142 \\
\hline Cottonseed & 35.3 & 37.3 & 36.7 & 35.4 & 35.0 \\
\hline Premix $^{2}$ & 191 & 190 & 192 & 197 & 197 \\
\hline
\end{tabular}


Cows were maintained under protocols approved by the Institutional Animal Care and Use Committee of the University of Wisconsin-Madison.

\section{Sample Collection}

Body weight and BCS (Wildman et al., 1982) were recorded for pens every 2 wk throughout the 11-wk trial. Daily BW change for each pen was determined by linear regression of BW measurements over time. Cows were milked twice daily at 0600 and $1700 \mathrm{~h}$ in a double-16 parlor (Metatron P21, GEA Farm Technologies, Bakel, the Netherlands), and milk yield recorded at each milking on individual cows (BoviSync, Eden, WI). Milk was sampled at both milkings on d 13 and 14 of the covariate period and on d 20, 21, 41 , and 42 of the treatment period. Milk samples were composited by pen and analyzed by AgSource Milk Analysis Laboratory (Menomonie, WI) for composition by infrared analysis using a Foss FT6000 instrument (method 972.12; AOAC International, 2016). Actual milk, ECM, and ECM feed conversion were calculated by week using average daily yield and DMI data. Milk energy density (Mcal kg-1) was calculated from NRC equations (NRC, 2001).

Forages, concentrates, TMR, and ort samples were collected weekly. During weeks of fecal collection for digestibility analysis, feed and ort collections were conducted on the same days fecal sampling was conducted. For all weeks, the nutrient intake was corrected for the nutrient content of the orts. All samples taken were frozen at $-20^{\circ} \mathrm{C}$ until analysis.

Fecal grab samples from each cow were obtained over a 56-h period from d 18 to 21 and d 39 to 42 of the treatment period and represented defecation every $4 \mathrm{~h}$ throughout a day. The sampling took place at $2000 \mathrm{~h}$ on the first day, 0800 and $2200 \mathrm{~h}$ on the second day, 0400 and $1200 \mathrm{~h}$ on the third day, and $0000 \mathrm{~h}$ on the fourth day. Samples were taken on an equivalent wet basis, composited by pen by week, and then dried at $55^{\circ} \mathrm{C}$ in a forced-air oven.

\section{Behavior}

Rumination was recorded daily for each cow using SCR HR-Tag neck collars (SCR Engineers Ltd., Netanya, Israel). Rumination data were averaged by pen by week to obtain average time spent ruminating.

\section{Laboratory Analysis and Calculations}

All forage, feed, TMR, ort, and fecal samples including those used for further analysis were dried in forcedair ovens at $55^{\circ} \mathrm{C}$ for $48 \mathrm{~h}$ for constituent analysis and $105^{\circ} \mathrm{C}$ for $48 \mathrm{~h}$ for $\mathrm{DM}$ determination. Samples used for analysis were then ground through a $1-\mathrm{mm}$ screen in a Wiley mill (Arthur H. Thomas, Philadelphia, PA). All samples were analyzed for OM (method 942.05; AOAC International, 2016), CP by combustion (Dumas combustion method; Vario Max CN; Elementar Americas Inc., Mt. Laurel, NJ), and amylase-treated NDF (aNDF) using $\alpha$-amylase and sodium sulfite in filter bags (Ferreira and Mertens, 2007). A subsample was ground using an abrasion mill (Udy Corp., Fort Collins, CO) equipped with a $1-\mathrm{mm}$ screen and then analyzed for starch content according to the sodium acetate buffer method (Hall, 2009). Indigestible NDF (iNDF) was determined by 288 -h in situ incubation in bags with a pore size of $25 \mu \mathrm{m}$ (Krizsan and Huhtanen, 2013). Potentially digestible NDF (pdNDF) is the difference between aNDF and iNDF. Concentrations of aNDF and iNDF were not ash-corrected. Total-tract apparent digestibilities were calculated using iNDF as the internal marker (Huhtanen et al., 1994). The calculated estimate of fiber digestibility (TTNDFD) and ruminal rate of degradation $\left(\mathrm{k}_{\mathrm{d}}\right)$ were determined as described by Lopes et al. (2015), using 24-, 30-, and 48-h in situ ruminal incubations. The TTNDFD equation was also rearranged to estimate the contribution of feed to gut fill:

$$
\begin{gathered}
\text { g of gut fill unit }(\mathrm{kg} \text { of DM.d })^{-1}=\mathrm{iNDF} \times\left(24 \mathrm{~h} \cdot \mathrm{d}^{-1}\right. \\
\left.\times \mathrm{k}_{\mathrm{pi}}\right)+\operatorname{pdNDF} \times\left[24 \mathrm{~h} \cdot \mathrm{d}^{-1} \times\left(\mathrm{k}_{\mathrm{pp}}+\mathrm{k}_{\mathrm{d}}\right)\right]
\end{gathered}
$$

where $\mathrm{k}_{\mathrm{pi}}=$ indigestible NDF passage rate $\left(3.33 \% \mathrm{~h}^{-1}\right)$, $\mathrm{k}_{\mathrm{pp}}=$ potentially digestible NDF passage rate $(2.67 \%$ $\left.\mathrm{h}^{-1}\right), \mathrm{k}_{\mathrm{d}}=$ degradation rate of pdNDF, calculated from in vivo $\mathrm{NDF}$ digestibility and $\mathrm{k}_{\mathrm{pp}}$, iNDF $=\mathrm{g}$ of iNDF $(\mathrm{kg} \text { of } \mathrm{DM})^{-1}$, and $\mathrm{pdNDF}=\mathrm{g}$ of pdNDF $(\mathrm{kg} \text { of } \mathrm{DM})^{-1}$.

The TMR feed results reported were by mathematical combination of individual feed ingredients in their respective DM contribution to TMR for the treatment and collection week, and were similar to the analyses of the composited TMR samples. We are introducing the term potentially fermentable DM (pfDM) to provide an energy basis for evaluation of diets and forages of varying ash and iNDF content, where DM is an unsatisfactory surrogate for feed energy potential. The calculation for pfDM is DM less ash and iNDF. Particle size of forage, TMR, and orts samples were determined by using the Penn State Particle Separator shaker box using 19- and 8-mm screens (Heinrichs et al., 1999).

\section{Statistical Analyses}

Intake, lactation performance, and rumination data were analyzed using the mixed model procedure of SAS 
(ver. 9.2, SAS Institute Inc., Cary, NC) for a completely randomized design with a covariate adjustment:

$$
\mathrm{Y}_{\mathrm{ijk}}=\mu+\mathrm{C}_{\mathrm{i}}+\mathrm{W}_{\mathrm{j}}+\mathrm{T}_{\mathrm{k}}+\mathrm{WT}_{\mathrm{jk}}+\mathrm{E}_{\mathrm{ijk}},
$$

where $Y_{i j k}=$ dependent variable, $\mu=$ overall mean, $C_{i}$ = fixed effect of covariate, $\mathrm{W}_{\mathrm{j}}=$ fixed effect of sampling week, $\mathrm{T}_{\mathrm{k}}=$ fixed effect of treatment, $\mathrm{WT}_{\mathrm{jk}}=$ interaction between sampling week and treatment, and $\mathrm{E}_{\mathrm{ijk}}=$ residual error. Pen was used as the experimental unit. Sampling week was included in the model as a repeated measure using the Akaike information criterion to select the best fitting covariate structure for each dependent variable. The interaction $\left(\mathrm{WT}_{\mathrm{jk}}\right)$ was removed from the model if $P>0.25$. Statistical significance and tendency were declared at $P \leq 0.05$ and 0.05 $<P \leq 0.10$, respectively. All reported values are least squares means. Treatment means were compared using the Bonferroni option. Digestibility and daily change in BW data were calculated using the same model but did not include a covariance adjustment.

\section{RESULTS AND DISCUSSION}

\section{Feed Ingredients and Diet Composition}

The whole-plant corn silages used for treatments were harvested at similar heights and had similar aNDF concentrations but differed in iNDF concentrations (Table 1). The toplage that was harvested $55 \mathrm{~cm}$ higher than the other silages had a substantially lower aNDF concentration and a ratio of pdNDF to aNDF between that of the control and calcium hydroxide-treated corn silage. This was expected because the lower portion of the stalk left in the field is highly lignified and has a high aNDF concentration. Treated stalklage harvested $14 \mathrm{~cm}$ lower than the other corn silages contained 428 $\mathrm{g}$ of pdNDF $\left(\mathrm{kg}\right.$ of $\left.\mathrm{OM}^{-1}\right)$ and $383 \mathrm{~g}$ of iNDF $(\mathrm{kg}$ of $\mathrm{OM})^{-1}$. As a comparison, 3 mini-silos of the same stalks were prepared without treatment, stored for the same duration, and analyzed. The untreated mini-silos contained $357 \mathrm{~g}$ of pdNDF $(\mathrm{kg} \text { of } \mathrm{OM})^{-1}$ and $500 \mathrm{~g}$ of iNDF $(\mathrm{kg} \text { of } \mathrm{OM})^{-1}$ (data not shown), indicating a successful treatment application. Particle size of the treated stalklage was greater than that of other silages, due to the random orientation of feeding a windrowed crop with a windrow pickup into the self-propelled forage harvester's cutterhead. At removal, the treated corn silage had a high $\mathrm{pH}$, a low level of lactate, and high levels of acetate, butyrate, and ethanol (Table 3 ). These results are similar to reported values for calcium oxide-treated whole-plant corn silage (Dahlke and Euken, 2013). The fermentation profile of the TRTCS suggests that this material might be aerobically un-
Table 3. Fermentation profile [ $\mathrm{g}(\mathrm{kg} \text { of } \mathrm{DM})^{-1}$, unless otherwise noted] of whole-plant and calcium hydroxide-treated corn silage ${ }^{1}$

\begin{tabular}{lcc}
\hline Item & WPCS & TRTCS \\
\hline pH $(-)$ & 4.09 & 5.81 \\
Lactate & 36.8 & 9.5 \\
Acetate & 5.9 & 43.2 \\
Lactate to acetate ratio & 6.28 & 0.22 \\
Propionate & $\mathrm{ND}^{2}$ & 6.8 \\
Butyrate & $\mathrm{ND}^{2}$ & 15.7 \\
Succinate & 2.9 & 3.5 \\
Formic acid & $\mathrm{ND}$ & 0.5 \\
Ethanol & 3.0 & 2.3 \\
\hline
\end{tabular}

${ }^{1} \mathrm{WPCS}=$ whole-plant corn silage; TRTCS $=$ treated whole-plant corn silage.

${ }^{2}$ Not detected.

stable. The low ambient temperature during feeding likely reduced spoilage for the silages prone to aerobic instability. During the week of transition, cows on the TRTCS diet had the lowest levels of intake and production. However, upon adaptation to the TRTCS diet, intake and milk production were highest in this group.

\section{Intake and Production}

Rations fed had similar aNDF concentrations with differing levels of pdNDF: $693,755,686$, and $731 \mathrm{~g}$ of pdNDF $(\mathrm{kg} \text { of } \mathrm{NDF})^{-1}$ for WPCS, BMR, TPL, and TRTCS, respectively (Table 4). We expected that TPL would have a pdNDF level similar to that of BMR but it was most similar to the WPCS, likely due to lower harvest height, differences in fiber quality across the field, or both. However, intake and milk production of the TPL treatment most closely matched that of BMR. Dry matter intake for TRTCS was $2.0 \mathrm{~kg} \mathrm{~d}^{-1}$ greater $(P=0.02$, Table 5$)$ than that of WPCS. The numerical difference between BMR and WPCS, $0.6 \mathrm{~kg} \mathrm{~d}^{-1}$, was similar to the $0.9 \mathrm{~kg} \mathrm{~d}^{-1}$ found in a meta-analysis of feeding trials comparing conventional and BMR corn silages (Ferraretto and Shaver, 2015). Milk production and DMI (Figure 1) showed a week by diet interaction $(P$ $<0.001$ ). During wk 7 of the trial, a non-fecal-sampling week, the BMR corn silage had visible red mold that was removed by hand by the feeder; this might explain the low intake (Figure 1). Similarly (data not shown), interactions for BMR digestibility data by week within the experimental period showed that digestibility for BMR treatments in wk 3 was the lowest of all week and treatment combinations. It would appear the decrease in digestibility began to occur during wk 3 and the effects on intake and production were not fully realized until wk 4, at which point they began to diminish.

Intakes of aNDF $\left(\mathrm{kg} \mathrm{d}^{-1}\right)$ were similar among treatments $(P>0.10$, Table 5$)$. The intake of pfDMI was greater for cows fed TPL and TRTCS than for cows fed 
Table 4. Chemical composition $\left[\mathrm{g}(\mathrm{kg} \text { of } \mathrm{OM})^{-1}\right.$, unless otherwise noted] and physical characteristics of experimental diets and orts

\begin{tabular}{|c|c|c|c|c|c|}
\hline Item & Covariate & \multicolumn{4}{|c|}{ Treatment $^{1}$} \\
\hline \multicolumn{6}{|l|}{ TMR } \\
\hline $\mathrm{CP}$ & 185 & 183 & 182 & 180 & 189 \\
\hline $\mathrm{aNDF}^{2}$ & 361 & 356 & 352 & 352 & 343 \\
\hline Indigestible NDF & 103 & 109 & 86 & 110 & 92 \\
\hline $\mathrm{NFC}$ & 401 & 406 & 413 & 419 & 420 \\
\hline Ash & 93 & 93 & 94 & 92 & 114 \\
\hline $\mathrm{pdNDF}^{3} \mathrm{~g}(\mathrm{~kg} \text { of } \mathrm{NDF})^{-1}$ & 714 & 693 & 755 & 686 & 731 \\
\hline TTNDFD,$\%$ of NDF & 44.5 & 44.5 & 50.9 & 47.9 & 53.5 \\
\hline \multicolumn{6}{|c|}{ TMR particle size ${ }^{5} \mathrm{~g}(\mathrm{~kg})^{-1}$ as-fed retained $( \pm \mathrm{SD})$} \\
\hline $19 \mathrm{~mm}$ & $219 \pm 40$ & $40 \pm 14$ & $39 \pm 19$ & $64 \pm 28$ & $31 \pm 10$ \\
\hline $8 \mathrm{~mm}$ & $507 \pm 88$ & $523 \pm 34$ & $549 \pm 24$ & $457 \pm 29$ & $467 \pm 31$ \\
\hline \multicolumn{6}{|c|}{ Orts composition, $\mathrm{g}(\mathrm{kg} \text { of } \mathrm{DM})^{-1}( \pm \mathrm{SD})$} \\
\hline aNDF & $389 \pm 20$ & $384 \pm 38$ & $378 \pm 15$ & $396 \pm 19$ & $361 \pm 17$ \\
\hline Indigestible NDF & $128 \pm 14$ & $140 \pm 21$ & $109 \pm 18$ & $145 \pm 16$ & $111 \pm 9$ \\
\hline
\end{tabular}

${ }^{1} \mathrm{WPCS}=$ whole-plant corn silage; BMR $=$ brown midrib corn silage; TRTCS $=$ treated whole-plant corn silage; TPL $=$ toplage and treated stalklage.

${ }^{2}$ aNDF $=$ amylase-treated NDF.

${ }^{3} \mathrm{pdNDF}=$ potentially digestible NDF.

${ }^{4}$ TTNDFD $=$ total-tract digestibility prediction (Lopes et al., 2015).

${ }^{5}$ Particle size was measured using the Penn State Particle Size Separator (Heinrichs et al., 1999).

WPCS $(P<0.05)$. However, intakes of iNDF were 0.5 $\mathrm{kg} \mathrm{d}^{-1}\left[7 \mathrm{~g}\right.$ of iNDF $\left.(\mathrm{d} \cdot \mathrm{kg} \text { of } \mathrm{BW})^{-1}\right]$ greater for WPCS and TPL than for BMR and TRTCS $(P<0.01)$. The ruminal clearance rate for pdNDF is greater than that for iNDF due to digestion; therefore, iNDF has a greater effect on ruminal fill than pdNDF. The treatments with the greatest iNDF intake had the least pdNDF intake, and consequently the calculated gutfill units between treatments were similar (Table 5). The reduced iNDF concentrations in BMR and TRTCS and the increased rate of digestion of TRTCS and TPL were likely significant contributors to the tendencies for greater intakes. Oba and Allen (2000a) likewise found increased intakes for low iNDF corn silage.

Milk production generally followed the patterns seen for intake. Milk and protein yield were greater for BMR and TRTCS $(P<0.01$, Table 5$)$ and tended to be greater for TPL $(P<0.10)$ compared with the WPCS diet. Ferraretto and Shaver (2015) also saw increased milk $\left(0.9 \mathrm{~kg} \mathrm{~d}^{-1}\right)$ and protein $\left(0.05 \mathrm{~kg} \mathrm{~d}^{-1}\right)$ production for BMR over WPCS. Their meta-analysis did not find differences in fat yield but did find reduced milk fat concentration $(0.11 \%)$. In the current study, we found that BMR and TPL diets had a numerical but nonsignificant reduction in milk fat concentration of a similar magnitude. Cows fed TRTCS had greater fat yield and
ECM production compared with those fed WPCS ( $P$ $<0.01)$.

\section{Feed Efficiency, Digestibility, and Behavior}

We detected no differences in BW, BW change, and BCS between treatments $(P>0.30$, Table 5$)$. The BMR treatment resulted in a tendency for greater milk $(\mathrm{DMI})^{-1}$ feed efficiency over WPCS. There was no difference in the ECM (OMI $)^{-1}$ feed efficiency or energy ratio of ECM (pfDMI $)^{-1}$ among treatments. In a restricted intake study of sodium hydroxide-treated sorghum silage, milk and SCM production increased by 2 and $1.5 \mathrm{~kg} \mathrm{~d}^{-1}(P=0.11)$, respectively (Ghebriel et al., 1981). The response in the current study was greater but could also be attributed to greater intakes due to cows being fed ad libitum.

No differences in DM digestibility or OM digestibility (OMD) were found between WPCS and BMR in the current study, in agreement with Ferraretto and Shaver (2015); we also found no difference in overall NDF digestibility (NDFD) between WPCS and BMR (Table 6). Ferraretto and Shaver (2015) reported a 2.5\% improvement in NDFD for BMR versus WPCS. Digestibility of pdNDF of the BMR ration was less $(P<0.01$, Table 6) than that of all other treatment, and the BMR 
Table 5. Effects of silage treatments on intake and production

\begin{tabular}{|c|c|c|c|c|c|c|c|}
\hline Item & \multicolumn{4}{|c|}{ Treatment $^{1}$} & $\mathrm{SED}^{2}$ & \multicolumn{2}{|c|}{$P$-value } \\
\hline DMI, $\mathrm{kg} \mathrm{d}^{-1}$ & $23.6^{\mathrm{b}}$ & $24.2^{\mathrm{ab}}$ & $24.8^{\mathrm{ab}}$ & $25.5^{\mathrm{a}}$ & 0.5 & 0.02 & $<0.001$ \\
\hline $\mathrm{pfDMI}^{3} \mathrm{~kg} \mathrm{~d}^{-1}$ & $19.1^{\mathrm{b}}$ & $20.3^{\mathrm{ab}}$ & $21.0^{\mathrm{a}}$ & $21.0^{\mathrm{a}}$ & 0.5 & 0.01 & 0.60 \\
\hline $\mathrm{aNDF}^{4}$ intake, $\mathrm{kg} \mathrm{d}^{-1}$ & 7.32 & 7.64 & 7.76 & 7.69 & 0.21 & 0.21 & 0.01 \\
\hline iNDF ${ }^{5}$ intake, $\mathrm{kg} \mathrm{d}^{-1}$ & $2.43^{\mathrm{a}}$ & $1.94^{\mathrm{b}}$ & $2.41^{\mathrm{a}}$ & $1.91^{\mathrm{b}}$ & 0.07 & $<0.001$ & $<0.01$ \\
\hline Gutfill units, ${ }^{7} \mathrm{~kg}$ & 5.37 & 5.59 & 5.71 & 5.08 & 0.21 & 0.05 & 0.03 \\
\hline Milk, $\mathrm{kg} \mathrm{d}^{-1}$ & $43.2^{\mathrm{b}}$ & $47.1^{\mathrm{a}}$ & $46.0^{\mathrm{ab}}$ & $48.0^{\mathrm{a}}$ & 1.0 & $<0.01$ & $<0.001$ \\
\hline Fat, \% & 3.40 & 3.30 & 3.32 & 3.37 & 0.13 & 0.84 & 0.03 \\
\hline Fat, $\mathrm{kg} \mathrm{d}^{-1}$ & $1.47^{\mathrm{b}}$ & $1.55^{\mathrm{ab}}$ & $1.55^{\mathrm{ab}}$ & $1.66^{\mathrm{a}}$ & 0.04 & 0.01 & 0.34 \\
\hline Protein, \% & $2.97^{\mathrm{ab}}$ & $2.96^{\mathrm{a}}$ & $2.94^{\mathrm{ab}}$ & $2.84^{\mathrm{b}}$ & 0.04 & 0.02 & 0.18 \\
\hline Protein, $\mathrm{kg} \mathrm{d}^{-1}$ & $1.29^{\mathrm{b}}$ & $1.39^{\mathrm{a}}$ & $1.38^{\mathrm{ab}}$ & $1.38^{\mathrm{a}}$ & 0.03 & 0.01 & 0.16 \\
\hline $\mathrm{ECM}, \mathrm{kg} \mathrm{d}^{-1}$ & $42.1^{\mathrm{b}}$ & $45.0^{\mathrm{a}}$ & $44.8^{\mathrm{a}}$ & $46.9^{\mathrm{a}}$ & 0.8 & $<0.01$ & 0.21 \\
\hline Milk (DMI) $)^{-1}$ & 1.84 & $\begin{array}{l}.00 \\
1.95\end{array}$ & $\begin{array}{l}2.09 \\
1.87\end{array}$ & 1.87 & 0.04 & 0.09 & $<0.001$ \\
\hline ECM $(\mathrm{OMI})^{-1}$ & 1.96 & 2.02 & 1.93 & 2.04 & 0.04 & 0.12 & 0.77 \\
\hline ECM $(p f D M I)^{-1}$ & 2.21 & 2.21 & 2.15 & 2.23 & 0.05 & 0.44 & 0.60 \\
\hline
\end{tabular}

${ }^{\mathrm{a}, \mathrm{b}}$ Means in the table with different superscripts differ $(P \leq 0.05)$.

${ }^{1} \mathrm{WPCS}=$ whole-plant corn silage; BMR $=$ brown midrib corn silage; TRTCS $=$ treated whole-plant corn silage; TPL $=$ toplage and treated stalklage.

${ }^{2} \mathrm{SED}=$ standard error of the difference.

${ }^{3} \mathrm{pfDMI}=$ potentially fermentable DM (OM intake - indigestible NDF intake).

${ }^{4}$ aNDF $=$ amylase-treated NDF.

${ }^{5} \mathrm{pdNDF}=$ potentially digestible NDF.

${ }^{6} \mathrm{iNDF}=$ indigestible NDF.

${ }^{7}$ Calculation in Materials and Methods.

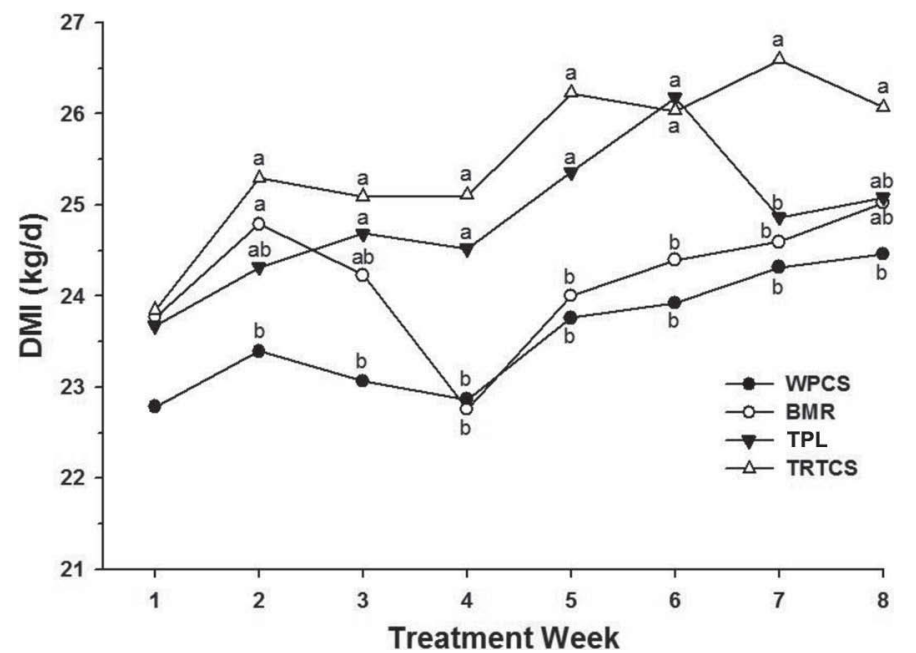

Figure 1. Least squares means of DMI by treatment and trial week. Treatments were whole-plant corn silage (WPCS), brown midrib corn silage (BMR), toplage and treated stalklage (TPL), and treated whole-plant corn silage (TRTCS). Within week, means with different letters $(\mathrm{a}, \mathrm{b})$ differ $(P<0.05)$. treatment had the least concentration of iNDF, resulting in an overall aNDF digestibility similar to that of WPCS and TPL. The TRTCS diet had similar pdNDF digestibility to corn of the same variety and field (the WPCS and TPL diets) but had, due to the calcium hydroxide treatment, lower iNDF concentrations. This resulted in TRTCS having an overall aNDF digestibility greater than all other treatments $(P<0.01)$. The patterns of intake and production closely followed the pattern of OMD. Intake and milk production were lowest for cows on the WPCS treatment, whereas cows fed TRTCS had the highest intake and milk production. The TTNDFD prediction from the in situ NDF degradation of TMR (Table 4) was lower than the measured in vivo NDF digestibility of the diets fed (Table 6), but the TTNDFD prediction ranked the diets similarly to the in vivo NDF digestibility. This could be due to slower passage rates or greater hindgut fermentation, but given the calculated gutfill unit to BW ratio of 7.1 to $7.9 \mathrm{~g}$ of rumen NDF ( $\mathrm{kg}$ of BW $)^{-1}$ and the expected maximum is $12 \mathrm{~g}$ of rumen NDF ( $\mathrm{kg}$ of BW) $)^{-1}$ (Mertens, 1987), it is likely that passage rate was slower. 
Table 6. Effects of silage treatments on total-tract digestibility of diet components

\begin{tabular}{|c|c|c|c|c|c|c|c|}
\hline Item & \multicolumn{4}{|c|}{ Treatment $^{1}$} & $\mathrm{SED}^{2}$ & \multicolumn{2}{|c|}{$P$-value } \\
\hline DM digestibility, \% & 70.0 & 70.6 & 71.0 & 72.6 & 0.6 & 0.07 & $<0.001$ \\
\hline NDF digestibility, \% & $51.4^{\mathrm{b}}$ & $53.0^{\mathrm{b}}$ & $52.1^{\mathrm{b}}$ & $58.4^{\mathrm{a}}$ & 1.2 & $<0.01$ & $<0.01$ \\
\hline pdNDF digestibility, ${ }^{3} \%$ & $77.0^{\mathrm{a}}$ & $71.2^{\mathrm{b}}$ & $75.5^{\mathrm{a}}$ & $77.6^{\mathrm{a}}$ & 1.6 & 0.01 & 0.03 \\
\hline Starch digestibility, $\%$ & $98.9^{\mathrm{b}}$ & $98.9^{\mathrm{b}}$ & $99.2^{\mathrm{b}}$ & $99.8^{\mathrm{a}}$ & 0.1 & $<0.01$ & 0.01 \\
\hline
\end{tabular}

a,b Means in the table with different superscripts differ $(P \leq 0.05)$.

${ }^{1} \mathrm{WPCS}=$ whole-plant corn silage; BMR $=$ brown midrib corn silage; TRTCS $=$ treated whole-plant corn silage; TPL $=$ toplage and treated stalklage.

${ }^{2} \mathrm{SED}=$ standard error of the difference.

${ }^{3} \mathrm{pdNDF}=$ potentially digestible NDF.

Starch digestibility was $98.9 \%$ or greater for all treatments, and fecal starch for all treatments was less than $1 \%$ (Table 6). The TRTCS diet had significantly lower fecal starch and improved starch digestibility. Alkali can be used as an agent to improve starch digestibility and was successful at doing so here. However, it can also lead to changes detrimental to starch digestibility when aerobic stability is a problem. Deschard et al. (1988) treated whole-crop wheat silage with sodium hydroxide, which resulted in increased in vitro digestibility, but in vivo starch digestibility in steers decreased from 959 to $790 \mathrm{~g} \mathrm{~kg}^{-1}$.

Cows fed WPCS spent more time ruminating (510 $\min \mathrm{d}^{-1}$ ) and more time ruminating per unit of DM intake $(P<0.05)$ than did cows fed either BMR or TRTCS (Table 7). Oba and Allen (2000b) did not find differences in time spent ruminating, eating, or chewing between BMR and conventional corn silage diets but did find increases with increased NDF concentration in the diet. All other treatments were similar in time ruminating per kilogram of aNDF intake and rumination per unit of gut fill. Milk fat concentration was similar among diets, indicating that effects of treatment on decreased time spent ruminating did not cause milk fat depression. Overall, BMR and TPL behaved similarly, having numerical or significant increases in intake, OMD, and production compared with WPCS. Significant or numerical improvements in intake, OMD, and production were detected for cows fed TRTCS compared with those fed BMR and TPL.

Aerobic stability of whole-plant corn silage treated with calcium hydroxide would be a concern for adoption of this silage. Stability can be a concern for treated stalklage (Tetlow et al., 1985, 1987; Deschard et al., 1987, 1988; Tetlow and Mason, 1987); however, due to the smaller mass and reduced feed quality compared with the toplage fraction, the economic risk on a farm is low by comparison. Due to the ability to optimize a ration, moderate risk, and performance of the fractionated corn silage, further research to elucidate harvest

Table 7. Effects of silage treatments on rumination behavior

\begin{tabular}{|c|c|c|c|c|c|c|c|}
\hline Item & \multicolumn{4}{|c|}{ Treatment $^{1}$} & $\mathrm{SED}^{2}$ & \multicolumn{2}{|c|}{$P$-value } \\
\hline Rumination time, $\min \mathrm{d}^{-1}$ & $510^{\mathrm{a}}$ & $474^{\mathrm{b}}$ & $487^{\mathrm{ab}}$ & $459^{\mathrm{b}}$ & 8 & 0.01 & 0.09 \\
\hline Rumination $\left.(\text { aNDF intake })^{3}\right)^{-1}$ & 70.3 & 64.0 & 63.6 & 61.4 & 2.9 & 0.05 & 0.29 \\
\hline Rumination $\left(\mathrm{iNDFI}^{4}\right)^{-1}$ & $218^{\mathrm{b}}$ & $254^{\mathrm{a}}$ & $199^{\mathrm{b}}$ & $261^{\mathrm{a}}$ & 14 & $<0.01$ & 0.01 \\
\hline Rumination (gutfill unit $\left.{ }^{5}\right)^{-1}$ & 94.9 & 84.5 & 86.2 & 95.8 & 5.1 & 0.10 & 0.04 \\
\hline
\end{tabular}

$\overline{\mathrm{a}, \mathrm{b}}$ Means in the table with different superscripts differ $(P \leq 0.05)$.

${ }^{1} \mathrm{WPCS}=$ whole-plant corn silage; BMR $=$ brown midrib corn silage; TRTCS $=$ treated whole-plant corn silage; TPL $=$ toplage and treated stalklage.

${ }^{2} \mathrm{SED}=$ standard error of the difference.

${ }^{3}$ aNDF $=$ amylase-treated NDF.

${ }^{4} \mathrm{iNDFI}=$ indigestible NDF intake.

${ }^{5}$ Calculation in Materials and Methods. 
and storage logistics and value of ration optimization, and continued work on chemical treatment of the stalklage fraction appear to be warranted.

\section{CONCLUSIONS}

Calcium hydroxide treatment of whole-plant corn silage and fractionated corn silage was effective at increasing intake and milk production over traditional harvest and storage techniques. The treatment of whole-plant corn silage resulted in silage having increased DM, OM, aNDF, and starch digestibility. Our results demonstrate the efficacy of feeding corn silage that is harvested in a 2-pass system that results in separate high-starch and high-fiber feedstuffs.

\section{REFERENCES}

AOAC International. 2016. Official Methods of Analysis. 20th ed. AOAC International, Rockville, MD.

Dahlke, G. R. and R. M. Euken. 2013. Calcium oxide and calcium hydroxide treatment of corn silage. Anim. Ind. Rep. AS 659, ASL R2774. Iowa State University Press, Ames.

Deschard, G., V. C. Mason, and R. M. Tetlow. 1988. Treatment of whole-crop cereals with alkali. 4. Voluntary intake and growth in steers given wheat ensiled with sodium hydroxide, urea or ammonia. Anim. Feed Sci. Technol. 19:55-66. http://dx.doi. org $/ 10.1016 / 0377-8401(88) 90054-5$.

Deschard, G., R. M. Tetlow, and V. C. Mason. 1987. Treatment of whole-crop cereals with alkali. 3. Voluntary intake and digestibility studies in sheep given immature wheat ensiled with sodium hydroxide, urea or ammonia. Anim. Feed Sci. Technol. 18:283-293. http://dx.doi.org/10.1016/0377-8401(87)90036-8.

Fahey, G. C., L. D. Bourquin, E. C. Titgemeyer, and D. G. Atwell. 1993. Postharvest treatment of fibrous feedstuffs to improve the nutritive value. Pages 715-766 in Forage Cell Wall Structure and Digestibility. H. G. Jung, D. R. Buxton, and J. Ralph, ed. ASACSSA-SSSA, Madison, WI.

Ferraretto, L. F., and R. D. Shaver. 2015. Effects of whole-plant corn silage hybrid type on intake, digestion, ruminal fermentation, and lactation performance by dairy cows through a meta-analysis. J. Dairy Sci. 98:2662-2675. http://dx.doi.org/10.3168/jds.2014-9045.

Ferreira, G., and D. R. Mertens. 2007. Measuring detergent fibre and insoluble protein in corn silage using crucibles or filter bags. Anim. Feed Sci. Technol. 2:335-340. http://dx.doi.org/10.1016/j. anifeedsci.2006.04.010.

Ghebriel, A. W., D. Wayne Kellogg, and D. D. Miller. 1981. Effect of sodium hydroxide treatment of sorghum silage on lactation of cows and on in vitro digestion. J. Dairy Sci. 64:792-797. http://dx.doi. org/10.3168/jds.S0022-0302(81)82649-5.

Haddad, S. G., R. J. Grant, and S. D. Kachman. 1998. Effect of wheat straw treated with alkali on ruminal function and lactational performance of dairy cows. J. Dairy Sci. 81:1956-1965. http://dx.doi. org/10.3168/jds.S0022-0302(98)75769-8.

Haddad, S. G., R. J. Grant, and T. J. Klopfenstein. 1994. Digestibility of alkali-treated wheat straw measured in vitro or in vivo using Holstein heifers. J. Anim. Sci. 72:3258-3265.

Hall, M. B. 2009. Determination of starch, including maltooligosaccharides, in animal feeds: Comparison of methods and a method recommended for AOAC collaborative study. J. AOAC Int. 92:42-49.

Heinrichs, A. J., D. R. Buckmaster, and B. P. Lammers. 1999. Processing, mixing, and particle size reduction of forages for dairy cattle. J. Dairy Sci. 77:180-186.

Huhtanen, P., K. Kaustell, and S. Jaakkola. 1994. The use of internal markers to predict total digestibility and duodenal flow of nutri- ents in cattle given six different diets. Anim. Feed Sci. Technol. 48:211-227. http://dx.doi.org/10.1016/0377-8401(94)90173-2.

Jackson, M. G. 1977. Review article: The alkali treatment of straws. Anim. Feed Sci. Technol. 2:105-130. http://dx.doi. org/10.1016/0377-8401(77)90013-X.

Jung, H.-J., D. A. Samac, and G. Sarath. 2012. Modifying crops to increase cell wall digestibility. Plant Sci. 185-186:65-77. http:// dx.doi.org/10.1016/j.plantsci.2011.10.014.

Krizsan, S. J., and P. Huhtanen. 2013. Effect of diet composition and incubation time on feed indigestible neutral detergent fiber concentration in dairy cows. J. Dairy Sci. 96:1715-1726. http:// dx.doi.org/10.3168/jds.2012-5752.

Lopes, F., K. Ruh, and D. K. Combs. 2015. Validation of an approach to predict total tract fiber digestibility using a standardized in vitro technique for different diets fed to high producing dairy cows. J. Dairy Sci. 98:2596-2602. http://dx.doi.org/10.3168/jds.20148665.

Mertens, D. R. 1987. Predicting intake and digestibility using mathematical models of ruminal function. J. Anim. Sci. 64:1548-1558.

Miller, J. E., J. L. Geadelmann, and G. C. Marten. 1983. Effect of the brown midrib-allele on maize silage quality and yield. Crop Sci. 23:493-496. http://dx.doi.org/10.2135/cropsci1983.0011183X0023 $00030013 x$

Nigon, B. J., K. J. Shinners, and D. E. Cook. 2016. Harvester modifications to alter composition and dry matter of corn-silage. Appl. Eng. Agric. Rev. http://dx.doi.org/10.13031/aea.32.11417.

NRC. 2001. Nutrient Requirements of Dairy Cattle. 7th rev. ed. Natl. Acad. Press, Washington, DC.

Oba, M., and M. Allen. 1999. Evaluation of the importance of the digestibility of neutral detergent fiber from forage: Effects on dry matter intake and milk yield of dairy cows. J. Dairy Sci. 82:589 596. http://dx.doi.org/10.3168/jds.S0022-0302(99)75271-9.

Oba, M., and M. S. Allen. 2000a. Effects of brown midrib 3 mutation in corn silage on productivity of dairy cows fed two concentrations of dietary neutral detergent fiber: 1 . Feeding behavior and nutrient utilization. J. Dairy Sci. 83:1333-1341. http://dx.doi.org/10.3168/ jds.S0022-0302(00)75000-4.

Oba, M., and M. S. Allen. 2000b. Effects of brown midrib 3 mutation in corn silage on productivity of dairy cows fed two concentrations of dietary neutral detergent fiber: 2. Chewing activities. J. Dairy Sci. 83:1342-1349. http://dx.doi.org/10.3168/jds.S00220302(00)75001-6.

Schwab, E. C., R. D. Shaver, K. J. Shinners, J. G. Lauer, and J. G. Coors. 2002. Processing and chop length effects in brown-midrib corn silage on intake, digestion, and milk production by dairy cows. J. Dairy Sci. 85:613-623. http://dx.doi.org/10.3168/jds.S00220302(02)74115-5.

Shreck, A. 2013. Use of alkaline treated crop residues as partial grain replacements for finishing cattle. PhD Diss. Animal Science Department, University of Nebraska, Lincoln.

Tetlow, R. M., and V. C. Mason. 1987. Treatment of whole-crop cereals with alkali. 1. The influence of sodium hydroxide and ensiling on the chemical composition and in vitro digestibility of rye, barley and wheat crops harvested at increasing maturity and dry matter content. Anim. Feed Sci. Technol. 18:257-269. http://dx.doi. org/10.1016/0377-8401(87)90034-4.

Tetlow, R. M., V. C. Mason, and G. Deschard. 1987. Treatment of whole-crop cereals with alkali. 2. Voluntary intake and digestibility by sheep of rye, barley and wheat crops ensiled with sodium hydroxide. Anim. Feed Sci. Technol. 18:271-281.

Tetlow, R. M., R. F. Wilson, and K. K. Bolsen. 1985. Effect of sodium acrylate and calcium and sodium hydroxides on the fermentation, digestibility, chemical composition and aerobic deterioration of whole-crop maize silage. Anim. Feed Sci. Technol. 12:91-99.

Wildman, E. E., G. M. Jones, P. E. Wagner, R. L. Boman, H. F. Troutt, and T. N. Lesch. 1982. A dairy cow body condition scoring system and its relationship to selected production characteristics. J. Dairy Sci. 65:495-501. http://dx.doi.org/10.3168/jds.S00220302(82)82223-6. 